\title{
Especialidades Médicas - Anestesiologia
}

\author{
Marcelo Luis Abramides Torres
}

Por que se escolhe uma especialidade médica em detrimento a outras? Gostaria de saber a resposta para ressaltar os pontos positivos da Anestesiologia para que fossem de encontro aos motivos pelos quais suas escolhas serão feitas. Claro que gostaria que um grande número de alunos da faculdade escolhesse nossa área.

Quando realizei minha escolha, há 30 anos, achei que tinha resolvido uma difícil equação. Unir minha vocação para pesquisa básica, adorava farmacologia, a possibilidade de ganho financeiro de uma especialidade médica que tinha forte ligação com os fármacos. Olhando para trás e vendo o quanto realizei dos meus sonhos, acho que não errei muito. Claro que não me tornei um pesquisador de cadeira básica, apesar de ter iniciado minha pós-graduação no departamento de Farmacologia do ICB, mas pude unir a pesquisa a atividade profissional médica.

Naquela época havia muito preconceito em relação aos anestesistas. Eram tachados como especialistas de segunda classe com pouco interesse médico e muito interesse financeiro. Pude ver que na grande maioria das vezes isso não era verdade. Mas existiam alguns profissionais que mereciam aquela fama. Por sorte pude conviver e aprender com verdadeiros médicos, na acepção da palavra. E eram esses em que me espelhava.

Nos dias atuais esse preconceito é muito menor, mas ainda existe aquela "rixa" entre cirurgião e anestesista. Claro que mais presente dos de maior faixa etária. O jovem cirurgião nos valoriza cada vez mais.
Dada a complexidade dos pacientes e dos procedimentos cirúrgicos, o anestesiologista deve ser um médico muito mais completo que os cirurgiões das várias especialidades que trabalhamos. Somos os clínicos e intensivistas da sala de operação.

Entretanto, para quem almeja ser o "chefe" da equipe cirúrgica a anestesiologia irá desapontar. Descreveria nossa função como o diretor de um show, entretanto, o artista principal não seremos nós e sim o cirurgião.

Sem dúvida nenhuma a anestesiologia é uma especialidade com amplo mercado de trabalho. Faltam anestesistas pelo Brasil todo. Os motivos são inúmeros, mas isso é uma realidade. Como consequência a remuneração também acaba sendo bastante atraente. Logo se ascende financeiramente, entretanto, logo também se atinge um patamar de ganhos que nos proporcionará um bom padrão de vida, mas não nos tornará milionários.

Porém é uma especialidade em que há de se conviver com plantões noturnos e em finais de semana. Salvo para quem trabalha com somente determinadas especialidades cirúrgicas, a grande maioria terá de cumprir por vários anos, plantões presenciais em hospitais.

Acho que raras são as especialidades médicas em que a rotina não acompanha o médico. Claro que sempre existem casos que desafiam nossa capacidade de raciocínio, nos impõe grandes habilidades e conhecimentos, entretanto, o dia a dia acaba sendo repetitivo. Existe uma máxima dentro 
dos meios anestesiológicos que expressa esse dia a dia: "Fazer anestesia são infinitos minutos de tédio, entremeados por momentos de absoluta apreensão, agitação e terror".

O médico anestesista desenvolve habilidades com inúmeros equipamentos e executa um grande número de procedimentos invasivos. Precisamos ter grande conhecimento no uso de ventiladores pulmonares, monitores, ultrassonografia (para acesso vascular central, bloqueios de plexos e bloqueios espinhais) e novos equipamentos que cada vez mais são incorporados a nossa prática clínica. Isso é muito diferente do que tinha a mão quando comecei minha residência no Hospital das Clínicas. Tínhamos somente 3 monitores cardíacos para todo centro cirúrgico. Pude presenciar uma grande mudança e evolução da especialidade nesses 30 anos!

Uma atividade correlata que acompanha nossa especialidade são os cargos administrativos dentro das instituições hospitalares. É muito comum vermos anestesiologistas coordenando o centro cirúrgico e assumindo várias diretorias médicas. Afinal, passamos grande parte da nossa vida dentro dessas instituições. Não temos consultório para dividir o tempo do nosso dia a dia.

Quando esse texto me foi solicitado, vieram com o convite alguns tópicos para serem abordados. A seguir transcrevo-os e se pudesse dar uma nota de zero a dez, para cada um deles, sendo zero desfavorável e dez muito favorável, assim seria:

1. Satisfação pessoal que a especialidade pode dar: 7;

2. Dificuldades da especialidade: 7 ;

3. Mercado de trabalho: 10;

4. Rotina: 5;

5. Salário (inicial, se estabiliza, se é pessoadependente): 8;

6. Preconceitos em relação à especialidade: 5.

Escolhas são difíceis e a grande dificuldade é por que raramente são reversíveis. Mudar de especialidade não é tarefa fácil nem comum. Mas também temos que saber lidar com nossas dúvidas e incertezas do dia a dia e trilhar um caminho sem olhar para trás! 